\title{
NOTES ON THE CULT OF THE FIFTEEN TIBERIOUPOLITAN MARTYRS IN MEDIEVAL BULGARIA
}

The cult of the fifteen Tiberioupolitan martyrs is one of the most intriguing cults in medieval Bulgaria. There are, however, a lot of questions about this cult, some of which I will address in this paper.

The earliest evidence of the cult at our disposal is their mention in the Evangelarium Assemani (late $10^{\text {th }}-$ early $11^{\text {th }}$ C.), at $29^{\text {th }}$ August. Only three of the martyrs are listed in this entry and the place of their martyrdom has already been located in Stroumitsa ${ }^{1}$. In the next manuscript which mentions them, the Liber Savvae $\left(11^{\text {th }}\right.$ C.), they are again related to Stroumitsa, albeit venerated on another date $-28^{\text {th }}$ November ${ }^{2}$. This is also the case in a later document - the so-called Ohridski apostol $\left(12^{\text {th }} \mathrm{C} \text {. }\right)^{3}$.

A very important source for this cult is the well-known Life of Clement of Ohrid by Theophylact of Ohrid - called: The martyrdom of the fifteen Tiberioupolitan martyrs (late $11^{\text {th }}$ or early $12^{\text {th }} \mathrm{C}$. $)^{4}$. The following points are of interest: first, the evidence by Theophylact as to where their martyrdom took place, where their cult was initially founded and when this event occurred. The answer to the last question is

\footnotetext{
1 В. Иванова-МавродИНова, А. ДжУРовА, Асеманиево евангелие. Старобългарски глаголически паметник от $X$ в. (художествено-историческо проучване), София 1981, p. 24-27; cf. I. Dujčev's preface, (ibidem, p. 8); cf. also A. МинчевА, Асеманиево евангелие - важный источник о старобольгарской культуре, Pbg 2, 1983, p. 91-95; Ц. ГРОздАнов, Месецослов Асемановог јеванһельа и старје зидно сликарство у Македонији, ЗЛУ 21, 1985, p. 14.

2 И.И. СРезневСКИй, Древние славянские памятники юсоваго письма, Санкт-Петербург 1868, р. 6, 84; К. Куев, Съдбата на старобългарската ргкописна книга през вековете, София 1986, p. 194.

3 С.М. КульБАкин, Охридская рукопись апостола конца ХІІ в., София 1907, р. 107 [= БС, 3]; cf. К. Куев, ор. cit., p. 205; Т. ЛАЛЕвА, Охридски апостол, [in:] Старобългарска литература. Енциклопедичен речник, еd. Д. ПЕтКАНова, София 1992, p. 309-310.

4 P. Gautier, L'episcopat de Theophylacte Hephistos, archeveque de Bulgarie (Notes chronologiques et biographiques), REB 21, 1963, p. 165; И.Г. ИлиЕв, Произведения на Теофилакт Охридски, архиепископ български, отнасящи се до българската история, [in:] FGHB, vol. IX, pars 2, ed. IDEM, Serdicae 1994, p. 42; cf. also I. Snegarov, Les sources sur la Vie et lactivite de Clement d'Ohrida, BBg 1, 1962, p. 105-106.
} 
clear, as the author dates the event during the reign of Emperor Julian the Apostate. The topography of the cult, on the other hand, is more problematic. Already in $\mathrm{N}$ 12, immediately after the long preface, Theophylact asserts without any clear reference to the previous text: In Macedonia, Theodoulos and Tatianos, pious and inspired men, broke into a pagan temple at night and destroyed the images. There is nothing unusual in this evidence, except for the note by P. Gauthier who, following an idea by K. Jireček, sustains that Theophylact moved the tale of the martyrdom of the Saints from Asia Minor to the Balkan Peninsula, taking the ethnonym Makedonios as toponym. According to the French scholar, Theophylact used a tale by the church historian Socrates about three martyrs named Makedonios, Theodoulos and Tatianos who suffered in the town of Myra (Phrygia, Asia Minor) ${ }^{6}$.

Then Theophylact continues with his tale of the fate of the other martyrs. Once again, the events take place in Asia Minor - in Nicaea, where some of them resided (Timothy, Comasios, Eusebios and Theodor) but left for Thessalonike due to their persecution. Soon after they moved to Tiberioupolis, (...) which lies north of Thessalonike, at the borders of Illyrian lands ${ }^{7}$.

This vague account is followed by details about the martyrs' deeds. Of interest for us is the evidence that Timothy became bishop of Tiberioupolis, while Theodor, also a bishop, though of an unknown place, participated in the first Catholic Council of Nicaea (325 AD) as one of the 318 Theophoric Fathers. This evidence is usually taken as a hagiographic myth ${ }^{8}$.

Further on, when listing the names of the other martyrs (Peter, John, Sergios, Theodor, Nikephoros, Basil, Thomas, Hierotheos, Daniel, Chariton), Theophylact discusses their martyrdom in Tiberioupolis ${ }^{9}$, where they died on $28^{\text {th }}$ November and were buried, each in their own casket bearing his name ${ }^{10}$. This account is followed by the tale of the invasion by a people called Omvri, said to have come from the south (sic!), who demolished Tiberioupolis. The caskets with the saints' relics remained beneath the ruins of the church-temple and were then forgotten ${ }^{11}$.

Let us now set aside the evidence of the arrival of the Bulgarians, their baptizing etc., which is of no interest for us here. I go on to discuss the very discovery of the relics, dated back to the reign of khan Boris I the Baptist (852-889), when the relics proved miraculous. The ruler ordered a special temple to be built for them

5 И.Г. ИлиЕв, ор. cit., p. 51.

6 К. ИРечЕК, Християнският елемент в топографическата номенклатура на балканските земи, ПСБКД 55-56, 1898, p. 248; cf. И.Г. Илиев, ор. cit., p. 51.

7 И.Г. ИлИЕв, op. cit., p. 55.

8 Ibidem, p. 55.

9 Ibidem, p. 57.

${ }^{10}$ Ibidem, p. 62.

${ }^{11}$ Ibidem. 
in the Bishopry of Bregalnitsa. This was carried out by Taridin, the local Comes. Although this is important as hagiographic evidence, I would rather emphasize the question posed by prof. Y. Ivanov, namely, why the relics needed to be moved to another place instead of repairing the old church or just building a new one in its place? ${ }^{12}$ It seems that the reason was not that Tiberioupolis no longer existed. On the contrary, the source mentions that the town not only survived but that its inhabitants were opposed to the removal of the relics. For this reason, only three of the caskets were actually moved (those of Timothy, Comasios and Eusebios) and placed in a specially built church-temple on the $28^{\text {th }}$ of August ${ }^{13}$. During the reign of tsar Symeon the relics of two more martyrs (Socrates and Theodor) were placed in the same temple ${ }^{14}$. Further on and without going into detail, Theophylact talks about a monastery named after them ${ }^{15}$.

I shall not deal with the canons and liturgies for the martyrs ${ }^{16}$ but note in passing that the title of one of their masses, believed by its discoverer, T. Vukanović, to be a second version, says they suffered in Тивєриополи простоглаголєнолит Gтюв ница ${ }^{17}$. I discuss this below.

As shown above, Theophylact's Vita speaks of two church-temples named after the martyrs. The first was the one underneath which the caskets remained after the demolition of Tiberioupolis. However, he does not mention this when talking about their funeral: The saints' caskets remained buried together with the demolished temple in which they were placed $(. . .)^{18}$. Nothing further is mentioned about this church-temple. In N 37, Theophylact already talks about the other church - in the bishopry of Bregalnitsa:

Thus the rumour reached the Bulgarian King Michael. And he [...] ordered a special churchtemple to be built for them in the bishopry of Bregalnitsa, which was accomplished [...]. ${ }^{19}$

\footnotetext{
${ }_{12}$ Й. Иванов, Северна Македония, София 1906, р. 75.

${ }^{13}$ И.Г. ИлиЕв, op. cit., p. 69.

${ }^{14}$ Ibidem.

${ }^{15}$ Ibidem, p. 77-78.

${ }^{16}$ И. СНеГАРов, История на Охридската архиепископия, vol. I, София 1924, p. 280; Т. Vukanović, The Legend of the martyrs of Tiberiopolis (Strumica), ВГ 7, 1971; Ц. ГРОзДАНОВ, Портрети на светителите од Македонија од IX-XVII в., Скопје 1983, p. 123; М. Стоянов, Опис на гръиките и други чуждоезични ръкописи в НБ “Кирил и Методий, София 1973, p. 56; Х. Меловски, Москополски зборник. Пролошки житија на светиите, vol. I, pars1, Скопје 1996, p. 29-31. On Moschopoulos' edition of the martyrs' mass see M.D. Peyfuss, Die Druckerei von Moschopolis 1731-1769. Buchdruck und Heiligenverehrung im Erzbistum Achrida, Wien 1996, p. 120-122 [= WAGSO, 13]; Г. ПоП-АтАНАСов, Нов прилог кон проучуваньето на Светиклиментовото химнограбско творечтво, БФСКОГЗ 7, 2001, р. 99-112.

${ }_{17}$ T. Vukanović, op. cit., p. 55.

${ }^{18}$ И.Г. ИлиЕв, op. cit., p. 62.

${ }^{19}$ Ibidem, p. 69.
} 
Then he mentions it at several places, calling it the church-temple in Bregalnits ${ }^{20}$, and at one point (N 53) he starts talking about a monaster $\mathrm{y}^{21}$.

The attempts at identifying the two churches began long ago. Already in the 1920's the Serbian scholar J. Tatić recognized the Stroumitsa church-temple in an area known as the fifteen saints, in the local oral tradition ${ }^{22}$.

In the seventies, archeological excavations were carried out on that site, which led to interesting results. The archaeologists discovered the narthex, the northern nave and the annex of the south-eastern side of a decussate churchtemple, three paleobyzantine brick-graves in the nave and the narthex with remains of a fresque added later, on which the fifteen Tiberioupolitan martyrs are depicted; a part of the oldest floor of the early Christian basilica with the northern stylobates and a part of the central apse. According to the archaeologists, D. Kotso and P. Milkovic-Pepek, the discovery of the northern stylobates and part of the oldest apse with a floor of mortar and part of the central apse, shows that the upper decussate, probably five-vaulted, church is built on top of a significantly older three-vaulted basilica containing three graves. The relation between the early Christian basilica and the three graves within is not quite clear. The archaeologists assume that they were built after the demolition of the early Christian basilica and assign their construction to the early Byzantine period $\left(6^{\text {th }}-8^{\text {th }} \mathrm{C}\right.$.). This conclusion is supported by the form of the crosses drawn in red color on the bricks of the first construction of the central vault. According to the two authors, it can be asserted with certainty that the early Christian basilica and the newly discovered central brick vault are not primarily related to the cult of the martyrs. They claim that this cult was moved to Stroumitsa from Asia Minor by emigrants ( $7^{\text {th }}$ and $8^{\text {th }}$ C.). In addition, and this is very important, the fresque with the fifteen martyrs in the central vault is added later to the construction of the vault, together with the decussate church-temple. Besides, they categorically relate the building of the decussate church with the cult of the martyrs by claiming that this place is related to the cult after the construction of the central vault within the building $^{23}$.

Hence the question of dating these fresques becomes very important. Similar images can be traced back to the later $9^{\text {th }}$ and early $10^{\text {th }}$ centuries, including ceramic icons from the monastery in the area of Touzlaluka in Preslav. For this reason, the fresques belonging to the church are dated at that period. The decus-

\footnotetext{
${ }^{20}$ Ibidem, p. 75.

${ }^{21}$ Ibidem, p. 77-78.

22 Ж. ТАТић, Два остатка византијске архитектуре у Струмичком крају, ГСНД 3, 1928, p. 83.

${ }_{23}$ Д. Коцо, П. Мильковик-Пепек, Резултатите од археолошките ископуваньа во 1973 г. во ирквата „св. 15 тиверириополски мәченици”, Стр 8-9, 1975-1978, p. 93-94.
} 
sate church is also dated at that period. This conclusion of the two authors is supported by the discovered fragments of fresques differing in style from the former ones, (late $11^{\text {th }}$ or early $12^{\text {th }} \mathrm{C}$.) and related to the renovation of the church-temple at the time of archbishop Theophylact of Ohrid ${ }^{24}$.

According to B. Aleksova who also participated in the excavations, the discovered church-temple was built on top of the graves of the martyrs who were initially buried in 16 vaults ${ }^{25}$, built in the late antique style and forming an area martyris. The most important of them is the big central vault which is situated beneath the nave of the decussate church, in the nave of the basilica ${ }^{26}$. Based on this, she concludes that this vault was built on top of the martyrs' graves and only later a new basilica was built by adding lateral rooms. Then a new decussate five-vault church-temple was built on top and it is still unclear whether it was built because the basilica was destroyed or simply in order to enlarge it. B. Aleksova assigns the construction of the decussate church-temple to the reign of emperor Justinian I (527-565). In addition, she takes the evidence by Theophylact to mean that this church-temple was destroyed and later rebuilt in the early $9^{\text {th }}-$ early $10^{\text {th }} \mathrm{C}$., during the intensive baptizing of the Slavs in Macedonia. B. Aleksova supports the dating of the fresques by means of the images of the martyrs found in the central vault and dated at the same period ${ }^{27}$. Based on the findings at the excavations and the discovered images, B. Aleksova concludes that the martyrs suffered in Stroumitsa, that they were buried there and that their cult developed there ${ }^{28}$.

The images are situated in the brick vault in the church crypt, on the western wall, divided into three areas: four images in the upper area, six in the middle

\footnotetext{
${ }^{24}$ Ibidem, p. 95-96.

${ }^{25}$ Recently B. Aleksova claimed that there were 19 vaults, which might be due to the discovery of some new vaults - Б. АлексовА, Св. тивериополски мәченици, комплекс на старохристиянски иьркви, [in:] Археолошка карта на Република Македонија, vol. II, Скопје 1996, p. 412.

${ }^{26}$ Б. Алексова, Епископијата на Брегалница - прв словенски ирковен и културно-просветен центар во Македонија, Прилеп 1989, р. 123; Б. АлекСовА, Св. тивериополски мбченици..., p. 413.

${ }^{27}$ Б. АлексовА, Епископијата на Брегалнииа..., p. 123; ЕАдем, Св. тивериополски мбчении...., p. 414; cf. Ц. ГроздАнов, Портрети..., р. 136, 137; Л. МАвРодиновА, Изображения на Тивериуполските маченици, открити неотдавна в Струмица, [in:] КMC, vol. XIII, София 2000, p. 139-144.

${ }^{28}$ Б. АлексовА, Епископијата на Брегалница..., р. 125-126:

Овие мошне значајни археолочки остатоии ги потврдуваат податоците ито ни ги дава Теофилакт. Мачениците ито настрадале во Струмица биле закопани во истиот град. На почвата на Македонија е создаден нивниот култ и нивното славенье. Поради тоа отпага секоја претпоставка дека култот можел да биде пренесен од Мала Азија, зашто, ако се работи за пренесуванье на веке создаден култ на друга територија или друг град, можат да бидат пренесени само мочти или реликвии на маченици. Во тој случај за нив не се градат гробови, бидејки од тоа нема потреба. Нивните реликви не се сместуваат на гробиштата. За нив се градат конструкции от типот на Confessio или тетогіа (...).
} 
and five in the lower areas. In this lower area only two images are preserved (one of them in part), in the middle area only the lower part of the first three images is destroyed while the heads are preserved. The images in the upper area have remained intact ${ }^{29}$. These images are recognized with the help of the text by Theophylact of Ohrid. The first image in the upper area is probably Timothy, because the represented figure is a bishop; the second and the third are, respectively, Comasios and Eusebios, while the fourth figure is the other bishop - Theodor. As is well-known, these four are the first who moved from Nicaea to Tiberioupolis. The next group comprises partly or completely destroyed images that are hard to recognize, although Ts. Grozdanov claims that the last saint in the third area is Thomas because he is depicted as a deacon ${ }^{30}$. Ultimately, the author supports the dating suggested by the archaeologists D. Kotso and P. Milkovic-Pepek (late $9^{\text {th }}-$ early $10^{\text {th }} \mathrm{C}$.), based on a stylistic analysis of the fresques, agreeing with them that these portraits are inspired by the classical base of the renewed Byzantine art from the late $9^{\text {th }}$ or the early $10^{\text {th }} \mathrm{C.}^{31}$

Aleksova's hypothesis would seem convincing if the other archaeologists had not concluded that the central vault within the church-temple initially belonged to the early Christian basilica which is unrelated to the cult of the martyrs and it was only in the $9^{\text {th }}$ and $10^{\text {th }} \mathrm{C}$. that this vault was related to it, together with the newly built decussate church ${ }^{32}$. Ts. Grozdanov does not comment on this at all, only noting in passing that he needed more proof ${ }^{33}$.

As to the second church-temple (the one in Bregalnitsa), it is identified by Aleksova with the cathedral discovered in 1984 near Kroupishte on Bregalnitsa, in the area of Kale. Within it, in the annex at the right side of the altar there is a decussate martyrium which, according to the archaeologists, was designed for placing the martyrs' relics. It is dated back to the mid- $9^{\text {th }}$ to early $10^{\text {th }} \mathrm{C}$. and for this reason Aleksova assumes that this is precisely the church built on Boris's orders where the relics of the Tiberioupolitan martyrs were placed on two occasions ${ }^{34}$.

Thus we reach the important issue of identifying Tiberioupolis with today's Stroumitsa, an issue which crucial for the cult. A significant amount of scholarly work has been done on it and I will only mention the main opinions. I begin with $\mathrm{K}$. Jireček who came up with the first consistent theory. His starting point is the name Tiberioupolis, which he connects to several towns, two in Asia Minor (the

${ }^{29}$ Ц. ГрОЗДАНОв, Портрети..., p. 136.

${ }^{30}$ Ц. ГрОздАнов, Портрети..., p. 136; cf. П. Миљковик-ПеПек, Најстарите светителски култови во Македонија, темели за самостојната Самоилова ирква и автокефалност на Охридската архиепископија, ЗММАЕИ.СУ 1, 1993, р. 19.

${ }^{31}$ Ц. ГрОзДАНОв, Портрети..., p. 136.

32 Д. КОцО, П. МильКОвиК-ПеПЕК, ор. cit., p. 94.

${ }^{33}$ Ц. ГрОЗДАНОВ, Портрети..., p. 135.

${ }^{34}$ Б. АлексовА, Епископиіата на Брегалница..., p. 126. 
first in Phrygia, south of the Bithynian Olympos, the second in Pisidia), a third in Armenia and three in the Balkan peninsula (the examined one in Macedonia, another one identified as the mysterious Velika and a third in Varna) ${ }^{35}$.

The second point made by Jireček is that the saints of Stroumitsa are mentioned only in books that originated in the diocese of the Ohridian archbishopry and could not be found elsewhere, say in Basil II's Menologia or other Greek manuscripts $^{36}$. By pointing out that Theophylact's Vita is the main source for identifying Tiberioupolis with Stroumitsa, Jireček lists the other texts in which this

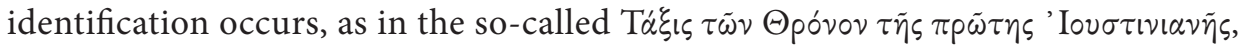

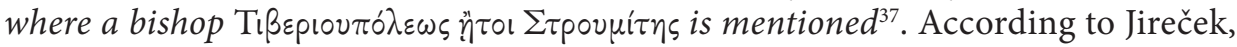
this manuscript dates back to the late $12^{\text {th }} \mathrm{C}$., around the time of the Bulgarian uprising in $1186^{38}$. However, a slightly earlier list reports the episcopy simply as $\dot{\eta} \sum \tau$ pov́ $\mu \tau \tau \zeta \alpha$ which allows him to conclude that this list is at the origin of the tradition of the later Byzantine notitiae to identify Tiberioupolis with Stroumitsa. It is very important that Jireček relates the appearance of the name Tiberioupolis to Stroumitsa with the theory that the archbishopry of Ohrid should be identified with Justiniana Prima which was founded around the second half of the $12^{\text {th }} \mathrm{C}$., as is well-known ${ }^{39}$. The other sources Jireček examines are the following:

- the inscription in the church Sv. Bogoroditsa Eleousa near Stroumitsa,

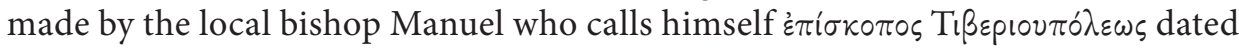
back ca. $1080^{40}$, although Jireček had some doubts about the dating ${ }^{41}$.

- a manuscript fragment from the $14^{\text {th }} \mathrm{C}$. by the name of some Kallinikos,

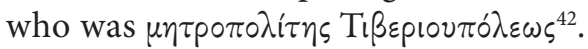

Further discussing the identification of Tiberioupolis and Velika and Varna, the famous scholar concludes as follows:

This uncertainty shows by itself that all identifications are grounded on hypotheses only and even the medievals considered them unlikely. The legend re-written by Theophylact deals with excavations in Stroumitsa, at the time of Boris I, when caskets with inscriptions were found. Added to this is another Life of Martyrs by an unknown author from the time of Emperor Julian I. Bishop Theodor, purported to be one of those who moved from

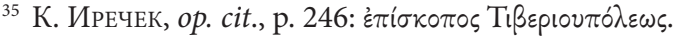

${ }^{36}$ Ibidem, p. 243.

${ }^{37}$ Vat. Gr. 828, fol. 354 r.; cf. H. Gelzer, Ungedruckte und Wenig bekannte Bistumverzeichnisse der orientalischen Kirche, BZ 1, 1892, p. 257.

${ }^{38}$ К. ИРЕЧЕК, op. cit., p. 245.

${ }^{39}$ Ibidem, p. 246, an. 1.

${ }^{40}$ L. Ретіт, Le monastere de Notre Dame de Pitie en Macedoine, ИРАИК 6, 1900, p. 6.

${ }^{41}$ К. ИРечеК, оp. cit., 246. This dating is confirmed by В. Джурич, Византийские фррески. Средневековая Сербия, Далмачия, славянская Македония, Москва 2000, p. 31. On older opinions vide В. Джурич, op. cit., p. 331-333.

${ }^{42}$ К. ИРечеК, op. cit., p. 246.
} 
Nicaea, did not participate in the Nicaean Council and cannot be found either in Bithynia or Phrygia, Galatia or any other province of Asia Minor. Bishops of that name who attended the Council came from Pisidia, Isauria and Kilikia. It is to be noted that Theophylact imports Phrygian martyrs from the age of Emperor Julian I to Macedonia and one of them was actually called Makedonios. This leads us to the assumption that the learned archbishop of Ohrid also imported a legend that originally took place in Tiberioupolis south of Nicaea in Asia Minor. ${ }^{43}$

Soon after Jireček's paper there appears an opposing view by the Benedictine scholar L. Petit who found Jireček's conclusions a little hasty, based on the evidence that a bishop of Tiberioupolis called Theoktistos attended the so-called Council of Photios in $879^{44}$. However, Petit does not say that Tiberioupolis and Stroumitsa fully coincide; according to him, the ancient Tiberioupolis was located near Stroumitsa in the place of today's village Banitsa, following the local tradition (as attested in Archimandrite Gerasimos) ${ }^{45}$.

It is also worth noting Y. Ivanov's opinion, according to which, if we accept Jireček's hypothesis that the legend and the town's name were imported from Asia Minor, we have to assume that in Stroumitsa there must have been even older legends of other Christian martyrs and that Theophylact used them in his Vita. Y. Ivanov, who obviously thinks that the import was made by Theophylact, takes them to be Slavic tales of an earlier time, as for instance, their being mentioned in the Evangelarium Assemani. He also recalls that the church-temple in Stroumitsa named after the martyrs and mentioned in 1348, is very likely to have been there much earlier ${ }^{46}$.

V. Zlatarski also deals with this problem in a separate article, as well as in his History of the Bulgarian State in the Middle Ages. In his paper he starts from Jireček's conclusion that the events took place in Asia Minor and were later imported to Bulgaria although, in his view, the importing of the legend and the cult occurred much earlier than Theophylact. He finds proof of this in much earlier evidence of their cult in Bulgaria as, for example, in the Evangelarium Assemani. However, Zlatarski does not believe that the importing of the legend and the cult occurred by means of texts only, but that there were other reasons. He finds one of those reasons in the mass emigration of Asia Minor population to the Balkan Peninsula at the time of the discovery of the martyrs' relics. He refers to a similar event during the reign of Emperor Nikephoros I Genikos (802-811), around Sept. 809 - Easter 810, according to Theophanes the Confessor ${ }^{47}$.

${ }^{43}$ Ibidem, p. 248.

${ }^{44}$ L. Petit, op. cit., p. 95-96.

${ }^{45}$ Ibidem, p. 100.

${ }^{46}$ Й. ИвАНОВ, op. cit., p. 209.

${ }^{47}$ В.Н. ЗЛАТАРСКИ, Легенда за откриване на мочите на Тивериуполските мбченици, [in:] 
In addition, V. Zlatarski thinks that Tiberioupolis and Stroumitsa were identified in the manuscripts as early as the $10^{\text {th }} \mathrm{C}$., that is, before the towns of the archbishopry of Ohrid received their classical or transliterated names, along with their Old Bulgarian names ${ }^{48}$. This identification began with the move of the relics to Stroumitsa, all details of the martyrs' cult being transferred from the demolished Tiberioupolis to the town of Stroumitsa, which had been flourishing as an important center since the early $10^{\text {th }} \mathrm{C}$., when tsar Symeon transformed it into a bishopry ${ }^{49}$.

According to V. Zlatarski, the legend of the martyrs was written down in Old Bulgarian probably at the beginning of the $10^{\text {th }} \mathrm{C}$. However, he emphasizes the fundamental role of Theophylact in importing the legend, as the latter seems to have artificially created the link between the Tiberioupolitan and the local Macedonian legends. For this purpose, the bishop is said to have presumed the existence of Tiberioupolis in Ancient Macedonia, as well as its identity with Stroumitsa. Thus he depicted the martyrs as moving from Nicaea to Macedonia, where they suffered martyrdom in the $4^{\text {th }} \mathrm{C}$. and were forgotten due to the Avars' invasion in the $6^{\text {th }} C .5^{50}$

As is noted in today's historiography, Zlatarski's hypothesis raises too many problems, although, paradoxically, it is still the basis of all subsequent reconstructions hostile to it. Recently, hypotheses dominate which, by contrast to the above-mentioned ones, claim that Tiberioupolis is a Macedonian town (in the contemporary political sense) and that Theophylact and his sources did not invent anything but correctly transmit the events.

The most important argument against Jireček - Zlatarski's hypothesis is the result of the archaeological excavations in Stroumitsa in the church-temple the fifteen Saints done by B. Aleksova, the main supporter of the continuity hypothesis. I should like to add a further point she made, namely that in Stroumitsa and the region, the cult of the forty martyrs was quite popular at that time ${ }^{51}$.

The continuity hypothesis is also supported by Ts. Grozdanov, based on the recently discovered images of the saints in the church-temple. But he is troubled by certain question which he does not answer. First, he does not refute Jireček in any way, whom he elsewhere accuses of concocted criticism. Nor does he refute Zlatarski, whose hypothesis he ironically calls very subtle. It is important to note that Ts. Grozdanov, like all other supporters of this hypothesis, does not comment or pay attention to Ph. Papazoglou's and others' strong claim that no Macedonian

IDEM, Избрани произведения, vol. I, София 1972, p. 195-196.

${ }^{48}$ Ibidem, p. 199.

${ }^{49}$ Ibidem, p. 202.

${ }^{50}$ Ibidem, p. 203.

${ }^{51}$ Б. Алексова, Епископијата на Брегалница..., р. 127-128. 
town named Tiberioupolis was known in Antiquity and the Middle Ages before the $11^{\text {th }}$ C. ${ }^{52}$ Ts. Grozdanov does not consider the results of the excavations published by T. Kotso and P. Milkovic-Pepek, nor does he mention the fact that the archeologists excavated 16 or 19 vaults (but not 15) in the area martyris in Stroumitsa, to cite B. Aleksova, which is used for the continuity hypothesis ${ }^{53}$.

There have been recent attempts at solving this problem. According to the Greek scholar A. Angelopoulos, the cult of the fifteen martyrs was wide-spread in the region of Stroumitsa and the name of the town where the relics were placed, did not change due to them but due to a historical factor - someone called Tiberius. In his view, a concrete proof of that is the preserved local name of the medieval site near Stroumitsa called Tiber's mountain ${ }^{54}$.

Considering all arguments, I think that Jireček's hypothesis is the most likely. Today we know that there was no town in late-antique Macedonia named Tiberioupolis. It is also beyond any doubt that the earliest evidence of a Macedonian Tiberioupolis dates back to the $11^{\text {th }} \mathrm{C}$. and refers to Stroumitsa. This convincingly shows that the identification Stroumitsa-Tiberioupolis was quite late. It first appeared in $1080^{55}$. We should note, as contemporary historiography does $^{56}$, that in the first Chrysobull by Basil II, some 60 years before (1019) the bishopry of Stroumitsa is listed only by its Bulgarian name ${ }^{57}$. This means that

\footnotetext{
${ }_{52}$ T. TAFEL, De Thessalonica eiusque agro. Dissertatio geographica, Berolini 1839, p. 294; Ф. ПАпАзоглу, Македонски градови у римског доба, Скопје 1957, р. 254-255.

${ }^{53}$ The problem of the number of martyrs in different copies of Theophylact's Vita still awaits clarification - cf. А. Ангелопулос, Петнадесетте Тивериополски мъченици в грбико-българското духовно предание, [in:] ИБПЦИАИ, vol. II, София 1984, p. 104.

${ }^{54}$ Ibidem, p. 102-110. Б. НиколовА, Устройство и управление на българската православна цьрква (IX-XVI в.), София 1997, p. 76-77, recalls Tafel's and Jireček's view and asks: Ако наистина такъв град (Тивериупол) не е съществувал на мястото на Струмииа, тогава кое е името на селището, от което са взети мощите на тивериуполските мәченици, за да бъдат пренесени в Брегалнииа? She then cites Angelopoulos' stance and compares Bulgarian and Byzantine sources on the town's name, concluding that the Bulgarian ones (including the charters by Basil II) do not mention Tiberioupolis while the Byzantine ones emphasize the Greek name - an observation, which is inexact at the least. Then the author rejects the identification of Theoktistos of Tiberioupolis, who attended the Council in 878-879, as a Macedonian bishop since he figures on the list together with prelates from Asia Minor, and also because Theophylact does not mention any bishopry of Tiberioupolis in his Vita. Finally, like other authors, Nikolova concludes that the only certain fact is that the cult of the Tiberioupolitan martyrs was widespread in the bishopry of Stroumitsa in the late $9^{\text {th }} \mathrm{C}$. and that the martyrs' relics were placed in the church-temple there.

${ }_{55}^{5}$ L. Ретіт, ор. cit., p. 95-96; cf. Ф. УСПЕнСкий, Акт отвода земли монастырю Богородицы Милостивой, ИРАИК 1, 1896, p. 1.

${ }^{56}$ L. Ретіт, op. cit., p. 94; В. ЗлАТАРСКИ, op. cit., p. 196.

${ }^{57}$ И. СнегАРОв, ор. cit., р. 56; Й. ИвАНОв, Български старини из Македония, София 1931, p. 522 .
} 
the identification occurred sometime between 1019 and 1080, presumably on ecclesiastical grounds, as it is found only in some church manuscripts ${ }^{58}$. After the above-mentioned Manuel, the founder of the church-temple Sv. Bogoroditsa

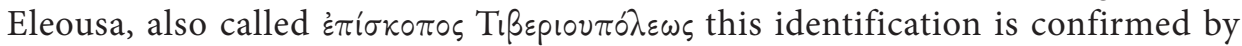

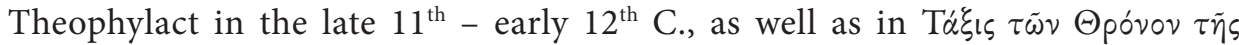

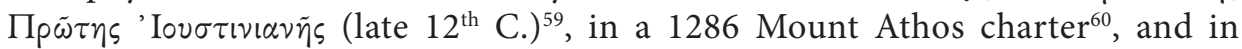
a bishop's notitia from the early $12^{\text {th }} \mathrm{C} .{ }^{61}$ At the same time, the counter-examples of Stroumitsa listed under its Bulgarian name only, are a lot more, including Greek and ecclesiastic sources ${ }^{62}$. Besides, today we cannot doubt that Theoktistos of Tiberioupolis, the priest who participated in the Council of Photios ${ }^{63}$, was indeed a bishop in Asia Minor ${ }^{64}$.

Assuming that Tiberioupolis and Stroumitsa were identified at some point in the mid- $11^{\text {th }}$ C., we can now move to the other important questions: on what grounds was this identification made and why? As we have seen above, there are two historiographic hypotheses on this matter. One is advanced by Zlatarski and obviously does not work. Apart from other minor problems, in his view, the emigrants from Asia Minor who spent only three years (809-812) in their new settlements, in that short period succeeded in building a new town called Tiberioupolis, in importing the relics, re-burying them, building the new church and disseminating the cult among the local Christian population, to the extent that 50 years later this cult was embraced by the newly baptized Bulgarians and Slavs. This is obviously impossible and for this reason, the only probable explanation is Jireček's - the identification was due to the cult of the martyrs in Stroumitsa ${ }^{65}$.

An obvious role in this respect was also played by the tendency to render toponyms archaic, as evidenced during the Byzantine rule of Bulgarian lands. Historiographically, this process is usually related to the origin and develop-

${ }^{58}$ L. Petit, op. cit., p. 94.

${ }^{59}$ H. Gelzer, op. cit., p. 257.

${ }^{60}$ F. Dölger, Aus den Schatzkammern des Heiligen Berges, München 1948, p. 298-301.

${ }^{61}$ J. Darouzes, Notitiae episcopatum ecclesiae Constantinopolitanae, Paris 1981, p. 372, Notitia $\mathrm{N} 13$.

${ }^{62}$ L. Petit, op. cit., p. 26, 27, 30, 31, 34. See other examples in F. Dölger, op. cit., p. 298-301;

J. Darouzes, op. cit., 372; FGHB, vol. VII, ed. G. Cankova-Petkova et al., Serdicae 1968, p. 102.

${ }^{63}$ Pseudosynodus Photiana, [in:] FGHB, vol. IV, ed. I. DujČEv et al., Serdicae 1961, p. 117.

${ }^{64}$ L. Ретіт, ор. cit., p. 96; Й. Иванов, Северна Македония..., p. 75, an. 2; А. КузЕв, За някои епархии в България през IX в., [in:] 1100 години от блажената кончина на св. Методий, vol. I, София 1989, p. 146.

${ }^{65}$ Near Kouklish, close to Stroumitsa, we can find another cult site related to the Fifteen Holy martyrs of Tiberioupolis. The site, however, is not examined by the archaeologists and a new churchtemple was built there in the 70's, which almost certainly destroyed any archaeological traces; cf. Д. КОцО, П. МильковИК-ПеПЕК, ор. cit., p. 96, an. 1. 
ment of the view that the archbishopry of Ohrid is to be identified as Justiniana Prima ${ }^{66}$.

Even if we accept Jireček's idea, however, there remains a further basic question: how did the cult arise in Stroumitsa? According to Ivanov this could have occurred through some local tradition related to other Christian martyrs ${ }^{67}$. This is quite possible in the light of the wide-spread cult of the forty holy martyrs which was attested by Aleksova. However, it could be that this was not due to written tradition but to material facts, such as the discovered vaults, etc. In any case, the cult had already been established in Stroumitsa by the late $9^{\text {th }} \mathrm{C}$. This is shown not only by Theophylact's evidence, but also by the images in the vaults which undoubtedly belong to this period.

This conclusion seems to contradict Theophylact's report of the relics' import under Boris I and Symeon. If the cult had originated in Stroumitsa, why did the kings have to move the relics to another place close by? This is a reasonable question and the answer is quite simple. When carefully reading Theophylact's Vita, we can see that they did not move the relics of all martyrs, but only of five of them (three under Boris and two under Symeon). Theophylact claims that the removal of the relics was impeded by the Tiberioupolitans' resistance but this account is obviously a hagiographic turn, because there is no mention of resistance during Symeon's reign and he still moved the relics of two other martyrs. All this shows that the Bulgarian rulers had no intention of moving all the relics but only to establish another center of their cult, where to place and venerate something quite valuable in the Middle Ages. This move could have resulted from the establishment of a new bishopry, especially if we assume that the big cult center on the Bregalnitsa, discovered by Aleksova, was really a bishopry ${ }^{68}$. Moving some relics to a new location does not mean that the old center had diminished; there is both direct and indirect evidence that it continued to function. One such direct testimony is a charter by Stefan Dušan dated around 1348-1352 which announces a donation to the monastery of Saint Archangels near Prizren and mentions a church-temple in Stroumitsa named after the martyrs: И юште црькови оу

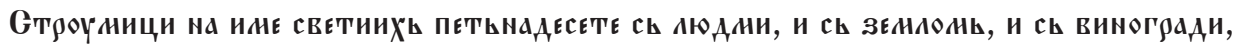

${ }^{66}$ К. Иречек, op. cit., p. 246, an. 1; М. Дринов, Исторически преглед на българската избрква от самото и начало и до днес, [in:] ІDем, Избрани съчинения, vol. II, София 1971, р. 120; Й. Иванов, Архиепископията и градът Първа Юстиниана, БПЦВ 10-12, 1903, p. 111; И. СнегАров, ор. cit., p. 80-81; cf. V. Tăpkova-Zaimova's notes in FGHB, vol. VII, p. 107; for further reading seе С. ПиривАтрич, Самуиловата държава, обхват и характер, София 2000, p. 192.

67 Й. Иванов, Северна Македония..., р. 209.

${ }^{68}$ Б. АлекСовА, Епископијата на Брегалница..., р. 128; ЕАрем, Брегалница - словенски ирковен и просветно-културен иентар на Балканот, [in:] Климент Охридски и улогата на Охридската книжевна школа во развитокот на словенската просвета, Скопје 1989. 


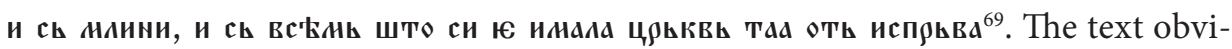
ously refers to the church-temple as having existed even earlier - от'ъ испрьва. Besides, this charter contains the written canons by Constantine Cabasilas and also the fact that it commemorates the first Stroumitsa date of venerating the martyrs, clearly shows that the initial center of the cult did not diminish. We can even assume that this initial center grew stronger, probably because it was a bishopry for a longer time.

On the other hand, as noted by Jireček, no Greek manuscripts mention the martyrs, except those coming from the diocese of the Ohrid archbishopry ${ }^{70}$. Together with the fact that Theophylact's Vita has an Old Bulgarian base ${ }^{71}$, this shows that the cult was imported soon after the baptizing of the Bulgarians. We also conclude this from the images in the vault which undoubtedly belong to that time. A last proof is the acrostic in the first version of the martyrs' mass, attested by G. Popatanassov, which says: КАИМ $\mathbf{H} \mathbf{H T}^{72}$. Kliment of Ohrid is the likely author of the Old Bulgarian Vita used by Theophylact, and although it was based on a Greek manuscript, the latter probably came from Asia Minor and not from Thessalonike or Constantinople.

Abstract. The cult of the fifteen Tiberioupolitan martyrs is one of the most intriguing cults in medieval Bulgaria. There are, however, a lot of questions about this cult, some of which I address in this paper.

The earliest evidence of the cult is their mention in the Evangelarium Assemani (late $10^{\text {th }}$ - early $11^{\text {th }}$ C.), at $29^{\text {th }}$ August, but only three of the martyrs are listed. Another important source for this cult is the well-known Life of Clement of Ohrid by Theophylact of Ohrid, called The martyrdom of the fifteen Tiberioupolitan martyrs (late $11^{\text {th }}$ or early $12^{\text {th }}$ C.). One of the most interesting evidences, however, is the very discovery of the relics, dated back to the reign of khan Boris I (852-889), when the relics proved miraculous.

According to the recent studies, the cult of the fifteen martyrs was wide-spread in the region of Stroumitsa and the name of the town where the relics were placed, did not change due to them but due to a historical factor - someone called Tiberius. On the other

${ }^{69}$ С. НовАковић, Законски спомениии српских држава средньега века, vol. V, Београд 1912, p. 682-705.

${ }^{70}$ К. ИРЕЧЕК, op. cit., p. 243; Ц. ГРОЗДАНОВ, Портрети..., р. 137; Ц. ГРОЗДАНОВ, Месеи,ослов, р. 15.

${ }^{71}$ К. ИРечеК, op. cit., p. 248; Ц. ГРОЗДАНОВ, Портрети..., р. 127; Н. ДРАГОвА, Старобългарските извори за житието на Петнадесетте Тивериуполски мбченици от Теобилакт Охридскu, SB, 2, 1970, p. 111-112; П. МилькОвик-ПепЕк, op. cit., p. 19. On the same page P. MilkovicPepek says: Воспоставуването на култот на св. 15 Тивериполски мачениии во времето на Климент Охридски, ито се поврзува и со стилските отлики на нивните представи од ова време во Цариград (...). It is not clear which images of the saints in Constantinople the author has in mind.

72 T. Vukanović, op. cit., p. 52-53; Г. ПОП-АТАНАСОв, op. cit., p. 100. 
hand, however, no Greek manuscripts mention the martyrs, except those coming from the diocese of the Ohrid archbishopry. The facts shown above proves that the cult was imported soon after the baptizing of the Bulgarians.

Translated by Anita Kasabova

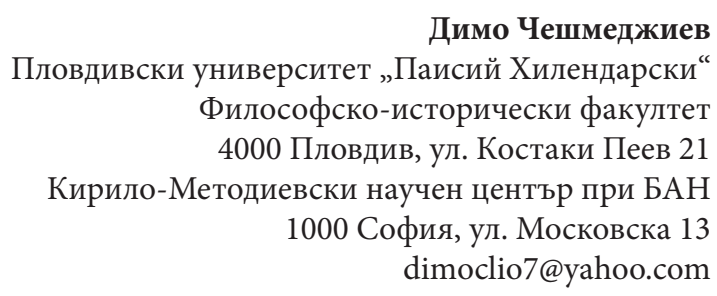

